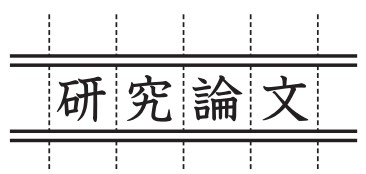

X 線照射による励起場形成を利用した純マグネシウムの表面改質現象

\title{
Surface Modification Phenomenon of X-ray Irradiated Pure Mg
}

\author{
船津恵介*・梅田純子**・高橋 誠 ${ }^{* *} \cdot$ 近藤 勝 義** \\ Keisuke FUNATSU, Junko UMEDA, Makoto TAKAHASHI and Katsuyoshi KONDOH
}

(Received September 3, 2012)

\begin{abstract}
Magnesium (Mg) and it alloys are highly corrosive due to their low standard electrode potential (SEP). The conventional methods to improve corrosion resistance of $\mathrm{Mg}$ alloys are anodic oxide film formation and chemical conversion treatment. However, these methods are expensive and also make it hard to recycle the $\mathrm{Mg}$ products with these treatments. In this study, unique oxide layer formed by radical reaction between pure $\mathrm{Mg}$ surface and radical species generated under X-ray irradiation was investigated. Pure $\mathrm{Mg}$ surface was modified by X-ray irradiation under atmospheric condition. XPS analysis indicated MgO layer was formed at the surface of X-ray irradiated pure Mg specimen. Cross-sectional observation by TEM showed the MgO layer was dense compared to the natural oxidation coating films. The thickness of surface modification layer by X-ray irradiation was increased with the increase of irradiation time. After salt water immersion test, X-ray irradiated pure Mg for 24 hours showed about four times corrosion resistance of the as-polished original pure $\mathrm{Mg}$. These results suggest that dense $\mathrm{MgO}$ layer formed by $\mathrm{X}$-ray irradiation on pure $\mathrm{Mg}$ surface were functioning as a protective film.
\end{abstract}

Key Words: Magnesium, Corrosion, Surface Improvement, SKPFM

\section{1. 緒言}

マグネシウム $(\mathrm{Mg})$ 合金は実用金属の中で最も低比重で あることから、自動車や二輪車などの移動体用部材に適用 することでその軽量化が可能となり、燃費改善や $\mathrm{CO}_{2}$ 排出 量削減といった省エネ・低炭素化効果が期待できる。一方、 $\mathrm{Mg}$ の標準電極電位は $-2.37 \mathrm{~V}^{1)}$ と構造材料として使われる 金属中で最も低いことから、異種金属と接触した際、その 卑な性質から異材界面において局部電池を形成し易く、ガ ルバニック腐食 ${ }^{2)}$ が問題となる。他方、アルミニウム (Al) やチタン (Ti) はそれぞれ $-1.66 \mathrm{~V} 、-1.63 \mathrm{~V}$ と標準電極電 位の低い材料であるが、酸素 $(\mathrm{O})$ との親和力が強く、表層 に緻密な酸化皮膜が形成し保護膜として機能することで、 高い耐腐食性を示す。しかしながら、Mg の自然酸化皮膜 は酸化マグネシウム $(\mathrm{MgO})$ の他に水和酸化物 $\left(\mathrm{Mg}(\mathrm{OH})_{2}\right)$ や 水素化物 $\left(\mathrm{MgH}_{2}\right)$ を含む多孔質構造を有するため、腐食環 境下では水分が酸化皮膜内部まで侵入し腐食が進行する ${ }^{3)}$ 。 そのため、 $\mathrm{Mg}$ 合金の耐腐食性を向上させる手法として、 一般に化成処理法や陽極酸化皮膜法などの表面皮膜処理を 施し、継手材との直接接触を抑制している ${ }^{4-6)}$ 。しかしなが ら、その処理過程において 6 価クロムなどの有害物質を使 用することや、使用後のこれら皮膜の剥離・除去が難しく、
$\mathrm{Mg}$ 部材のリサイクル性が低下するなどの課題を有してい る。本研究グループでは、有害物質を含まず、リサイクル 性を低下させない新たな防食技術として電子線照射法を提 案した ${ }^{7)}$ 。本手法では、試料表面に対する電子線照射により、 最表面に存在する絶縁層内の欠陥に励起電子が捕獲される ことで表面電位が低下し、Mg の耐腐食性が向上すること を明らかにした。

そこで、本研究では、真空下での電子線照射と比較して、 より簡便な電子励起場の形成方法としてX 線を励起源とし て使用した。溶液中や大気中といった水分が存在する環境 下にX 線などの放射線を照射した場合、水分子 $\left(\mathrm{H}_{2} \mathrm{O}\right)$ の電 離が生じ、ヒドロキシルラジカル $(\mathrm{OH} \cdot)$ や水素ラジカル $(\mathrm{H} \cdot)$ といったラジカルが発生する ${ }^{8)}$ 。一般に、ラジカルは反応

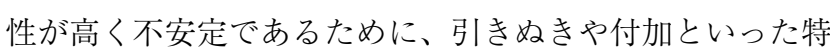
異な反応が生じる。そのため、薄膜形成や機能性高分子の 製造工程などで広く利用されている ${ }^{9} 。$ 。えに、大気䨌囲 気中における試料表面への X 線照射によっても、水の電離 により生じるラジカルと金属試料間での反応を通じて、特 異な物性・構造を有する酸化物層の形成が予想される。本 研究では、上記の反応により $\mathrm{Mg}$ 試料表面に形成される特 異な酸化物層を解析し、塩水浸漬状態での $\mathrm{Mg}$ 試料の腐食 挙動に及ぼす酸化物生成膜の影響について調査・考察した。

*大阪大学大学院工学研究科（干 565-0871 大阪府吹田市山田丘 2-1）

Graduate School of Engineering, Osaka University (2-1 Yamadaoka, Suita, Osaka, 565-0871 Japan)

**大阪大学接合科学研究所 ( T 567-0047 大阪府茨木市美穂ヶ丘 11-1)

Joining and Welding Research Institute, Osaka University (11-1 Mihogaoka, Ibaraki, Osaka, 567-0047 Japan) 


\section{2. 実験方法}

本研究では、X 線異物検出装置に組み込まれている X 線 源（X 線強度最大值 $10 \mathrm{keV})$ を用いて純 $\mathrm{Mg}$ 試料表面（純 度 $99.95 \%$ ）に電子励起場を形成し、ラジカル反応による 特異な酸化物層を形成させた。試料の平滑度を確保するた め、 $\mathrm{SiC}$ 耐水研磨紙にて $\# 4000$ まで研磨し、粒子径 $0.25 \mu \mathrm{m}$ のダイヤモンドペーストを用いたバフ研磨により鏡面仕上 げを施した。その後、エタノール中において超音波洗浄を 施し、試料最表面に対して 12 時間および 24 時間 X 線照射 を行った。なお、本研究では、比較材として同様の手法に て鏡面仕上げを施した未照射の純 $\mathrm{Mg}$ 試験片を 0 時間照射 材として評価した。

$\mathrm{X}$ 線照射による $\mathrm{Mg}$ 試料最表面における化学結合状態の 変化について、X 線光電子分光法 (XPS : X-ray photoelectron spectroscopy) を用いて解析した。計測試料には大気暴露材 と 24 時間照射材を使用した。ここで、大気暴露材として は、1 1 ケ以上の大気暴露処理を行った純 $\mathrm{Mg}$ 試験片を使 用した。XPS 測定の線源には、X 線照射装置よりも十分に 小さいエネルギーを持つ $\mathrm{MgK} \alpha(1253.6 \mathrm{eV})$ 線源を用いるこ とで、XPS 時の照射エネルギーの影響は無いと考える。ま た、帯電による結合エネルギー変化の補正には $284.6 \mathrm{eV} の$ C1s ピークを用いた ${ }^{10)}$ 。

次に、走査型ケルビンプローブフォース顕微鏡 (SKPFM : Scanning Kelvin Probe Force Microscope)により計測される表 面電位から、電子励起場の形成による表面電位の変化量を 定量的に評価した。SKPFM は試料表面を走査する探針と 試料の間に交流電圧を印加して静電気力による探針の振動 から試料の表面電位を計測する装置であり、探針と試料表 面間での接触電位差 ( $V_{C P D}$ : Contact potential difference) を測 定する ${ }^{11-13)}$ 。本研究では、各試料の計測前に、化学的に安 定で酸化皮膜を形成しない白金試料を用いて、その表面電 位が $0 \mathrm{~V}$ となるようにキャリブレーションを実施すること で、0 時間、12 時間、2 4 時間照射材における表面電位の絶 対值を精密に計測した。

$\mathrm{X}$ 線照射が $\mathrm{Mg}$ 試料の腐食現象に及ぼす影響を調査する ために、既往研究 ${ }^{14-15)} に て$ 多く用いられている塩水濃浸漬 試験を行った。本実験では、温調式ホットスターラーを用 いて溶液温度を $303 \mathrm{~K}$ に保持した 5 mass\% 塩化ナトリウム 水溶液 $1000 \mathrm{ml}$ 中で 60 秒間の塩水浸漬試験を実施した。試 験過程において、次式に示す酸化・還元反応により水素が 発生する ${ }^{16)}$ 。

アノード反応 $: \mathrm{Mg} \rightarrow \mathrm{Mg}^{2+}+2 \mathrm{e}^{-}$

カソード反応 : $2 \mathrm{H}_{2} \mathrm{O}+2 \mathrm{e}^{-} \rightarrow 2 \mathrm{OH}^{-}+\mathrm{H}_{2}$

マグネチックスターラーを用いて、塩水中で搅拌子を $420 \mathrm{rpm}$ で回転することで、上記の腐食により試料表面に 発生する微小な水素ガスの気泡を除去した。さらに、溶在
酸素が腐食現象に与える影響を排除すべく、塩水溶液にア ルゴンガスを $1.5 \mathrm{~L} / \mathrm{min}$ で注入した。腐食試験後、水溶液中 の $\mathrm{OH}^{-}$増加による $\mathrm{pH}$ 変化から算出した $\mathrm{Mg}$ 試験片の腐食 速度を比較することでX 線の照射により形成した緻密な酸 化物層が腐食現象に及ぼす影響を定量的に評価した。

\section{3. 実験結果と考察}

$3.1 \mathrm{X}$ 線照射による表面状態変化の調査結果

一般に、大気中の水分／水蒸気へ $X$ 線が照射された場合、 水の電離により $\mathrm{OH} \cdot や \mathrm{H} \cdot$ といった反応活性なラジカルが 発生する ${ }^{8)}$ 。なかでも、 $\mathrm{OH} \cdot$ は標準電極電位が $2.80 \mathrm{~V}$ と活 性酸素中で最も強力な酸化力を有するために、次式に示す 反応により、周囲から電子と水素イオンを奪い安定な $\mathrm{H}_{2} \mathrm{O}$ に変化する ${ }^{17)}$ 。

$\mathrm{OH} \cdot+\mathrm{H}^{+}+\mathrm{e}^{-}=\mathrm{H}_{2} \mathrm{O}$

したがって $\mathrm{Mg}$ の自然酸化皮膜上に $\mathrm{OH}$ ・が生成した場合、 自然酸化皮膜中に存在する分子から水素を奪うことで安定 な $\mathrm{H}_{2} \mathrm{O}$ に変化し、 $\mathrm{Mg}$ 表面を改質すると考えられる。

そこで本研究では、X 線照射によるラジカル反応が試 料表面に及ぼす影響を調査するために、24 時間材におけ る $\mathrm{Mg}$ 表面酸化皮膜の組織構造と形成形態を 1 ケ月以上の 大気暴露処理を施した大気暴露材の自然酸化皮膜と比較し た。まず、各試料の SEM-EDSによる組織観察結果を Fig. 1 に示す。一般に、Mg 表面の自然酸化皮膜は Fig. 1(a)に 示すような多孔質構造を有する ${ }^{18)}$ 。他方、24 時間照射材に おいて多孔質皮膜層は確認されず、Fig. 1(b) に示す平滑な 組織が確認された。また、EDS の元素分析結果より、大気
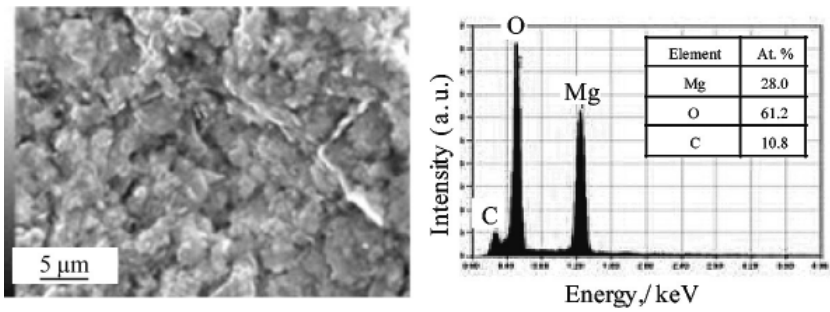

(a) Naturally formed oxide film
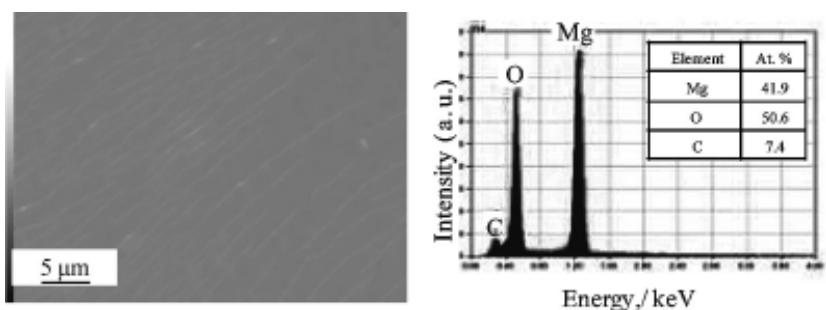

(b) X-ray irradiated Mg surface

Fig. 1 SEM image and EDS analysis results of naturally formed $\mathrm{MgO}$ layer (a) and X-ray irradiated pure $\mathrm{Mg}$ surface (b) 
暴露材では、 $\mathrm{Mg}$ と $\mathrm{O}$ の原子量比がおよそ $1: 2$ の割合で検 出されたのに対して、24 時間照射材ではほぼ1：1の割合 で検出された。これらの結果は、24 時間照射材の表面層が 自然酸化皮膜とは異なる構造を有する酸化物層であること を意味しており、X 線照射により生じたラジカルが反応す ることで試料表面が変質したことを示唆している。この表

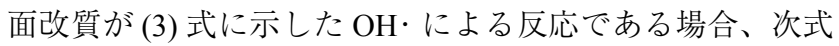
に示すような反応が $\mathrm{Mg}$ 表面にて生じ、 $\mathrm{MgO}$ 単相になると 考えられる。

$\mathrm{Mg}(\mathrm{OH})_{2}+2 \mathrm{OH} \cdot=\mathrm{MgO}+\mathrm{O}+2 \mathrm{H}_{2} \mathrm{O}$

$\mathrm{MgH}_{2}+2 \mathrm{OH} \cdot+\mathrm{O}=\mathrm{MgO}+2 \mathrm{H}_{2} \mathrm{O}$

そこで、XPS を用いて試料表面の Mg および O の結合状 態を調査し、上記仮説を検証した。大気暴露材、24 時間 照射材それぞれの Mg2p と O1s の XPS スペクトルを Fig. 2 に示す。Fig. 2(a) より、大気暴露材においては、金属状態 $\mathrm{Mg}[\mathrm{M}]$ の結合エネルギーのピークに加えて水酸化物・酸化 物状態に対応する結合エネルギー ${ }^{19)}(51.6 \mathrm{eV})$ のピークを確 認した。後者のスペクトルは $\mathrm{Mg}$ 試料表面に自然形成され

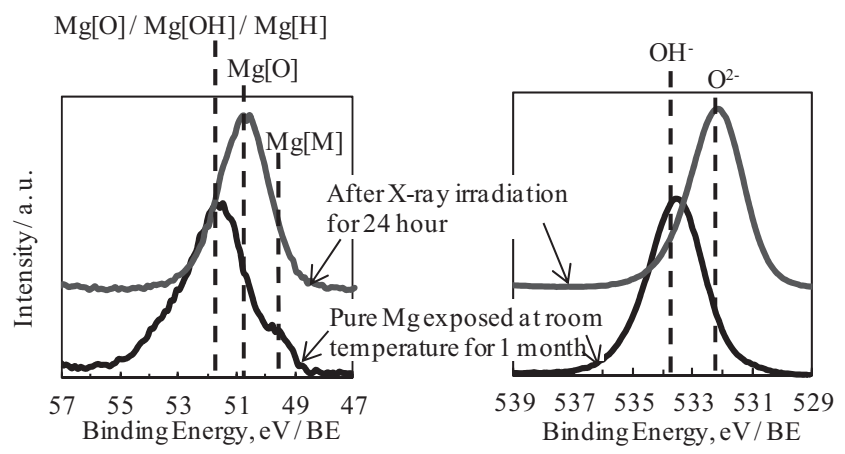

(a) $\operatorname{Mg} 2 \mathrm{p}$

(b) $\mathrm{O} 1 \mathrm{~s}$

Fig. $2 \mathrm{Mg} \mathrm{2p} \mathrm{(a)} \mathrm{and} \mathrm{O} \mathrm{1s} \mathrm{(a)} \mathrm{core} \mathrm{level} \mathrm{XPS} \mathrm{spectra} \mathrm{of} \mathrm{each} \mathrm{Mg}$ specimens surface.
た酸化皮膜に由来するものと考えられる。

他方、24 時間照射材においては、 $\mathrm{Mg}[\mathrm{M}]$ のスペクトルは 検出されず、酸化物単体 $\mathrm{Mg}[\mathrm{O}]$ の結合エネルギー ${ }^{20)}(50.6$ $\mathrm{eV})$ に対応するスペクトルのみ確認した。さらに、Fig. 2(b) に示す $01 \mathrm{~s}$ のスペクトルにおいても大気暴露材にて検出さ れた $\mathrm{OH}^{-}$のピークが消滅し、酸化物状態に対応した $\mathrm{O}^{2-}$ の ピークの顕著な増加が確認された。これは、X線の照射に よって、試料表面に存在する $\mathrm{Mg}(\mathrm{OH})_{2}$ の脱水素反応が生じ、 $\mathrm{MgO}$ が生成したことを意味している。以上の結果より、X

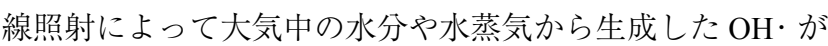
自然酸化皮膜と反応し、水素を奪うことで $\mathrm{Mg}$ の最表層は $\mathrm{MgO}$ 単相へと構造変化したと考えられる。

続いて、X 線照射により形成される $\mathrm{MgO}$ 層の組織構造 および形成形態に関して、TEMによる試料表面の組織観察 を行い、自然形成される $\mathrm{MgO}$ 層と比較した。1 月以上 の大気暴露処理後の $\mathrm{Mg}$ 試料（大気暴露材）の表面に自然 形成された $\mathrm{MgO}$ 層の TEM 観察結果を Fig. 3 に、24 時間 照射材の TEM 観察結果を Fig. 4 に示す。

Fig. 3(a)に見るように、自然形成される $\mathrm{MgO}$ 層は数マ イクロから数百ナノメートル程度の空孔が存在する多孔質 な構造を呈した。他方、Fig. 4(a)に示す 24 時間照射材で は、試料表面に $50 \mathrm{~nm}$ 程度の厚みを持つ緻密な $\mathrm{MgO}$ の表 面改質層を形成した。以上の結果より、X 線照射によって 生じるラジカル反応による酸化物層は、構成要素として $\mathrm{Mg}(\mathrm{OH})_{2}$ を含まない緻密な $\mathrm{MgO}$ 単一の表面改質層である と言える。また、活性な $\mathrm{OH}$ ・分子が上記の脱水素反応にお ける $\mathrm{MgO}$ 形成過程における核となることで緻密化が進行 したものと推察される。

\subsection{X 線照射による表面改質が腐食現象へ及ぼす影響}

$\mathrm{X}$ 線照射により生成した緻密な $\mathrm{MgO}$ 層を有する純 $\mathrm{Mg}$ 試 料表面に対して、SKPFMを用いてその電位分布を計測した.

Fig. 5 に示すように、通常、 $\mathrm{MgO}$ などの絶縁物によって金 属試料表面が覆われた場合、膜厚の増加に従って試料の電 気的特性は低下する ${ }^{21)}$ 。Fig. 5 に見るように、X 線照射時

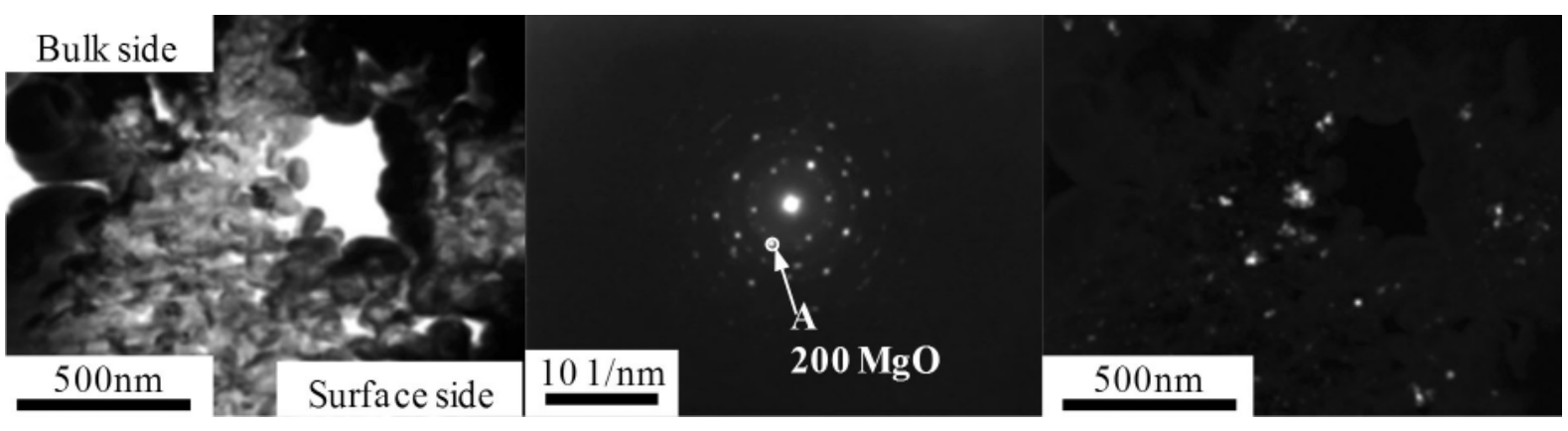

(a) Bright-field image

(b) Diffraction pattern

(c) Dark-field image

Fig. 3 TEM image of naturally formed MgO layer (a), electron diffraction pattern of (a) area (b) and the corresponding A area dark field image (c). 


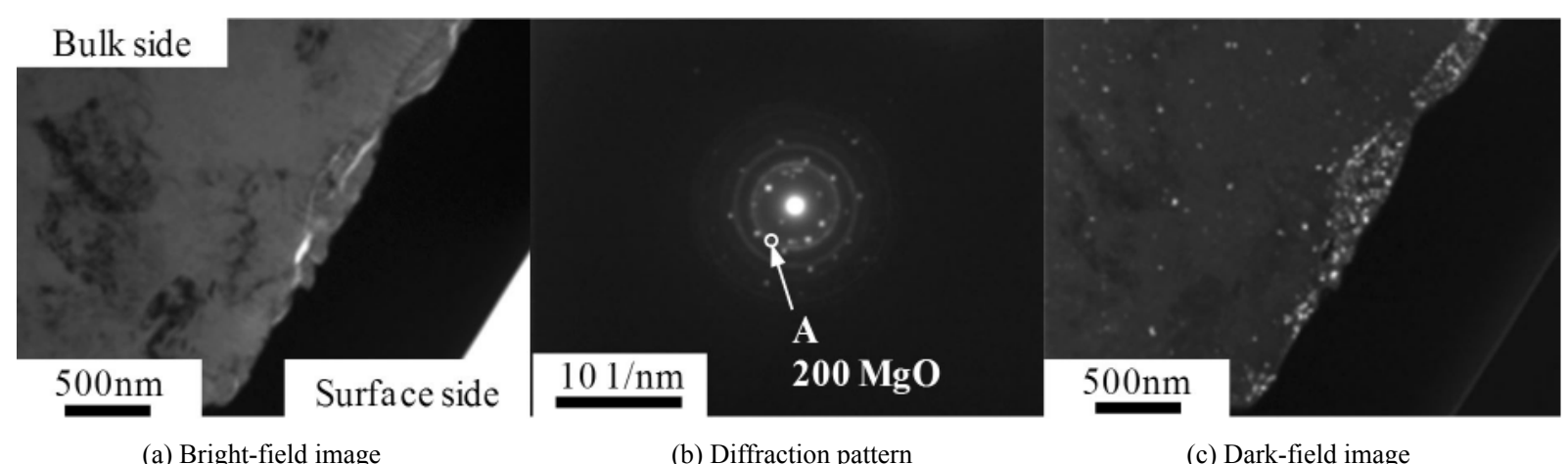

Fig. 4 TEM image of X-ray irradiated Mg surface (a), electron diffraction pattern of (a) area (b) and the corresponding A area dark field image (c).

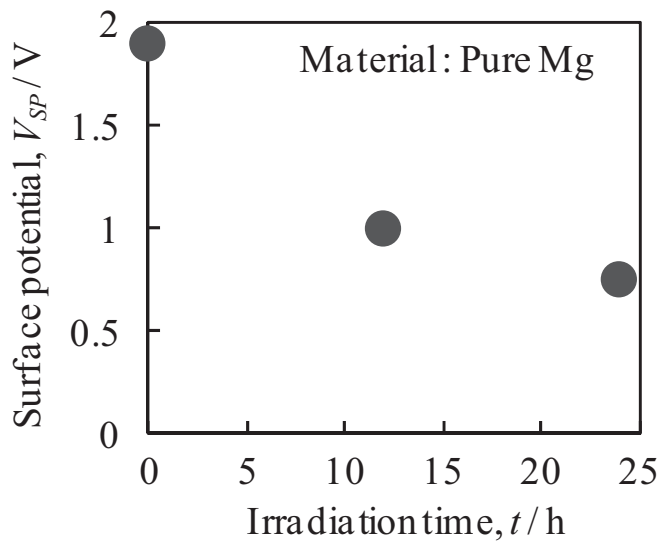

Fig. 5 Changes in surface potential of pure Mg specimen on X-ray irradiation time.

間の増大に伴い表面電位は低下した。この結果は照射時間 の増大によって試料表面の $\mathrm{MgO}$ 層の厚みが増加したこと を意味しており、前項の結果を踏まえると、X線照射によ り発生したラジカルと Mg 試料表面との反応が進行したこ と示唆している。

15 分間の塩水浸漬試験前後における純 $\mathrm{Mg}$ 試験片の外観 図を Fig. 6 に、試験終了後の水溶液の $\mathrm{pH}$ 変化より算出し た $\mathrm{Mg}$ の腐食速度を Fig. 7 にそれぞれ示す。Fig. 6(b) より、 $\mathrm{X}$ 線を照射した純 $\mathrm{Mg}$ 試料では、 $\mathrm{Mg}$ の腐食による黒色領域 が減少した。画像解析ソフトを用いて 0 時間、12 時間、24 時間照射材における黒色領域の面積率を算出した結果、そ れぞれ $49 \% 、 27 \% 、 11 \%$ となり、X 線照射時間の増加と ともに腐食領域は減少した。さらに、Fig. 7 に示す Mgの 腐食速度においても、X線照射時間の増加に従って、腐食 速度が低下し、24 時間照射材では約 $1 / 4$ に低下した。上記 の結果は、先ほどの皮膜厚さの傾向とも一致しており、X 線照射時間の増加による $\mathrm{Mg}$ の耐腐食性向上は試料表面に 形成された緻密な $\mathrm{MgO}$ 層の成長により発現したものと推 察される。したがって、X 線を照射した純 $\mathrm{Mg}$ では試料最

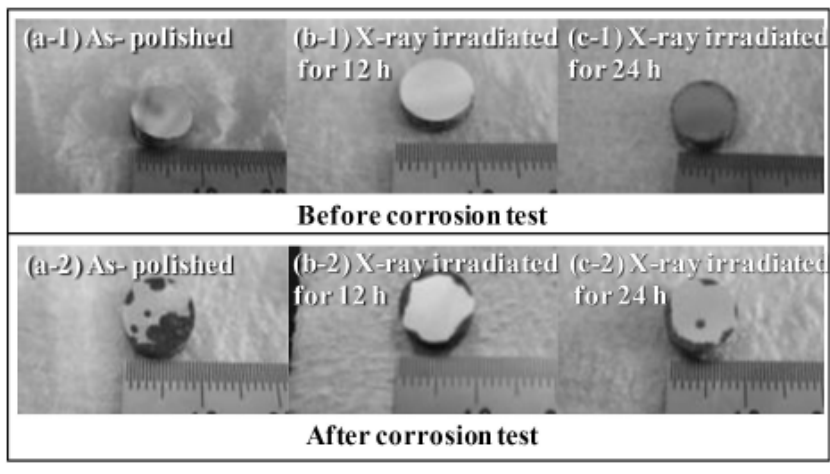

Fig. 6 Appearance of as-polished pure $\mathrm{Mg}$ (a), X-ray irradiated pure $\mathrm{Mg}$ for $12 \mathrm{~h}(\mathrm{~b})$ and X-ray irradiated pyre $\mathrm{Mg}$ for $24 \mathrm{~h}(\mathrm{C})$ before and after salt water immersion corrosion test.

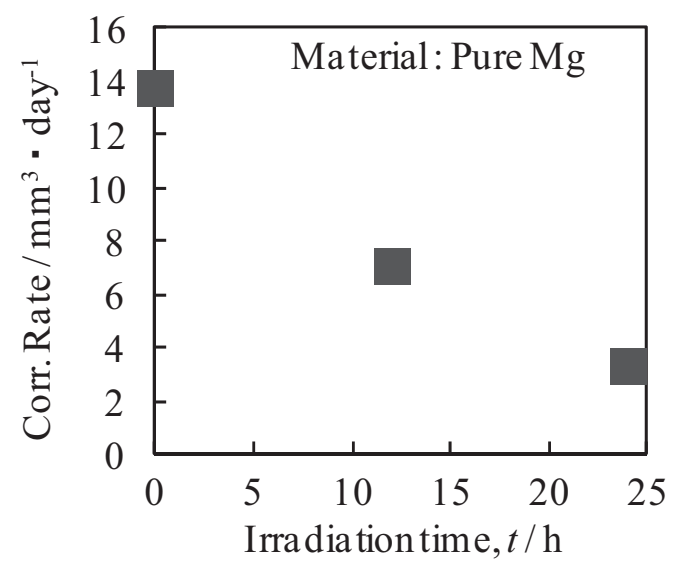

Fig. 7 Dependence of corrosion rate on X-ray irradiation time.

表面に $\mathrm{MgO}$ 皮膜が緻密に形成し、照射時間の増加に伴い 膜厚が増大する結果、腐食環境下において安定な保護膜と して機能することで $\mathrm{Mg}$ の耐腐食性が向上したと結論づけ られる。 


\section{4. 結 論}

本研究では、X 線照射下において生成される水分由来の ラジカルと $\mathrm{Mg}$ 試料表面間での反応により形成される特異 な酸化物層について構造解析を行い、塩水浸漬状態での腐 食挙動について調査した。以下に得られた知見を示す。

1) X線照射により純 $\mathrm{Mg}$ 試料表面に、構成要素として $\mathrm{Mg}(\mathrm{OH})_{2}$ を含まない緻密な $\mathrm{MgO}$ 単一の表面改質層が形 成されることを明らかにした。これは、X線照射によっ て生じる $\mathrm{OH}$ ・が試料表面と反応し、 $\mathrm{Mg}(\mathrm{OH})_{2}$ を含む自 然酸化皮膜中から水素を奪うことで安定な $\mathrm{MgO}$ に変化 したことに起因すると考えられる。

2) X 線照射による表面改質層の膜厚は照射時間の増加に 伴って増大した。また、塩水浸漬試験の結果、X線を照 射した試料では、表面に形成された緻密な $\mathrm{MgO}$ 層が保 護膜として機能することで腐食速度が約 $1 / 4$ に低減し、 $\mathrm{Mg}$ の耐腐食性向上が確認された。

\section{謝 辞}

本研究は公益財団法人軽金属奨学会および科学研究費助 成事業（課題番号 24656446）による研究助成により実施し た。ここに深く感謝申し上げる。

\section{参考文献}

1) 日本マグネシウム協会(編)、“マグネシウム技術便覧”、(2000)、 カルロス出版.

2) Avedesian, M. M., Baker, H., "Magnesium and Magnesium Alloys", ASM International, OH, (1999).

3）小野幸子、“マグネシウムの表面現象と酸化皮膜の成長”、表 面技術、Vol. 62, (2011) pp.198-203.

4) 根本茂、“初歩から学ぶマグネシウム”、(2002)（株）工業調査会.

5) 高谷松文、“ $\mathrm{Mg}$ の表面処理技術の最近動向”、軽金属学会、 Vol. 50, (2000) pp. 567-576.

6) 日野実、平松実、村上浩二、西條充司、金谷輝人、“電子機器 用 $\mathrm{Mg}$ 製品への導電性陽極酸化技術の開発”、まてりあ、Vol. 44, (2005) pp. 47-49.

7) Funatsu, K., Takei, R., Umeda, J., and Kondoh, K., "Electron Excitation Effect of Pure Mg Surface on initial Corrosion Phenomenon", Transaction of JWRI, Vol. 40, (2011) pp. 9-14.

8) 山下真一、“高エネルギー重粒子線による水の放射性分解”、
基礎科学ノート、Vol. 16, (2009) pp. 10-13.

9) 手老省三、真嶋哲朗、“フリーラジカル”、(2008), 米田出版.

10）日本表面科学会(編)、“ $X$ 線光電子分光法”、(1998)、丸善(株).

11) Sommerhalter, Ch., Glatzel, Th., Matthes, Th.W., Jager-Waldau, A., Lux-Steiner, M.Ch., "Kelvin probe force microscopy in ultra-high vacuum using amplitude modulation detection of the electrostatic forces”, Applied Surface Science, Vol. 157, (2000) pp. 263-268.

12) Kitamura, S., Suzuki, K., Iwatsuki, M. "High resolution imaging of contact potential difference using a novel ultrahigh vacuum non-contact atomic force microscope technique", Applied Surface Science, Vol. 140, (1999) pp. 265-270.

13) Takei, R., Imai, H., Umeda, J., and Kondoh, K., "Relationship between Surface Potential Difference and Galvanic Corrosion of Magnesium Alloy Using SKPFM" Transactions of JWRI, Vol. 39, (2010) pp.75-80.

14) Pardo, A., Merino, M., C., Coy, A., E., Viejo, F., Arrabal, R., and Feliú, S., Jr., "Influence of microstructure and composition on the corrosion behaviour of $\mathrm{Mg} / \mathrm{Al}$ alloys in chloride media", Electrochimica Acta, Vol. 53, (2008) pp. 7890-7902.

15) Yoo, B., Shin, K., R., Hwang, D., Y., Lee, D., H., and Shin, D., H., "Effect of surface roughness on leakage current and corrosion resistance of oxide layer on AZ91 Mg alloy prepared by plasma electrolytic oxidation”, Applied Surface Science, Vol. 256, (2010) pp. 6667-6672。

16) Van, M. J., and Pourbaix, Magnesium, M., in: M. Pourbaix (Ed.), Atlas of Electrochemical Equilibria in Aqueous Solution, Pergamon Press, Oxford, (1966).

17) 日本化学会(編)、“化学便覧”、(2004)、丸善(株).

18）岡本剛、井上勝也、“腐食と防食”、(1977)、大日図書.

19) Friedrichs, O., Sanchez-Lopez, J. C., Lopez-Cartes, C., Dornheim, M., Klassen, T., Bormann, R., and Fernandez, A., "Chemical and microstructural study of the oxygen passivation behavior of nanocrystalline $\mathrm{Mg}$ and $\mathrm{MgH}_{2}$ ", Applied Surface Science, Vol. 252, (2006) pp. 2334-2345.

20）渡辺健彦、山下司平、平石信、“AZ31B マグネシウム合金板 材の超音波接合性に及ぼす表面処理の影響”、軽金属、Vol. 51, (2001) pp. 521-527.

21）井本立也、兼松太、斉藤譲一、村川享男、“アルミニウム酸 化皮膜の表面電位に関する研究”、軽金属、Vol. 23, (1973) pp. 528-534. 